\title{
Detention Home Teens as Tutors: A Cooperative Cross-Age Tutoring Pilot Project
}

\author{
David B. Lazerson \\ Florida International University, USA
}

\begin{abstract}
Concerned professionals in the juvenile justice field frequently express concern for effective programs that help youth offenders successfully rejoin society. This mixed-method pilot study, involved detention home teens functioning as tutors for special education students in a public school. Tutors experienced gains in self-esteem and overall school/social attitude.
\end{abstract}

Several factors have been identified (Caliber, 2002; Leone, Mayer, Malmgren, \& Misel, 2000 ) that put youth at risk for delinquency and other anti-social, behavioral problems. These dynamic factors may include poor academic achievement, lack of identification to the child's school, a peer support group that engages in and encourages problem behaviors, poor interfamilial relations, low self esteem, and a lack of identification to one's local neighborhood. The situation is further compounded when schools practice inconsistent and inequitable disciplinary measures (Skiba \& Peterson, 2000). The end result often leads to substance abuse, school dropout, delinquency and sometimes violence.

The problem is further exacerbated by the trend towards punishment and retributive sanctions rather than rehabilitation for youth offenders (Empey, Stafford, \& Hay, 1999). This may lead the offender to a feeling of helplessness, which can lead to recidivism and a continuation of the anti-social behaviors. Several researchers (Leschied, Jaffe \& Willis, 1991; Henggeler, 1989) have found that quick-fix type programs do not really work for youth offenders and that once incarcerated the likelihood of re-offending actually increases. In a 5-year longitudinal study (Bullis, Yovanoff, Meuller \& Havel, 2002) reported that youth released from the youth detention system performed poorly integrating back into the community. Clearly there is a need for practical and effective rehabilitative programs to help our youth rejoin society as productive, successful members.

The technique of cross-age and peer interactive learning, or peer tutoring (PT), has long been found to offer a variety of benefits for both the tutee and the tutor, including improvements in behavior and social skills (Kamps, Kravits, Stolze, \& Swaggart, 1999; Lazerson, 1988). This has occurred in both school related settings, such as the traditional classroom (Gautrey, 1990), as well as non-academic settings such as the sports field, music instrument practice, etc. Lazerson (1980) found that behavioral problem tutors and tutees experienced significant gains as a result of engaging in consistent tutoring sessions. This current cross-age peer tutoring trial project was designed to help meet the unique needs and demands of youth already processed through the juvenile justice system. Individuals from a detention home (DH) in western New York State would function as tutors for younger students in a Buffalo, New York public school.

\section{Method}

\section{Participants}

All new research projects have some degree of risk involved. Risk was intensified since the study required detention home youth coming into the public school and interacting with the students. Three detention home teenagers would come to the school to tutor the younger tutees. The PT would begin on a six-week trial basis, with the detention home participants tutoring every school day for one 
period of up to 60 minutes. Three additional detention home teens, with similar backgrounds and educational difficulties, were chosen as the control group.

\section{The Tutors - Brief Profiles}

According to the law, the three tutors, John, Sean \& Lynn, were "habitually truant, disobedient, ungovernable, incorrigible, and beyond control of parents and other lawful authority." Each of them was adjudicated in a formal court hearing and placed in a secured group home because, according to sworn testimony, there was "significant likelihood" that they would either abscond or continue to engage in delinquent activity.

John, a 15 year old youth, had been in foster care or institutions since he was two years old. The detention home staff reported that John arrived at the group home "fighting, cursing, and swearing." This was his $11^{\text {th }}$ placement in 13 years. Sean, another 15 year old, was identified as a "sneaky, lying con-artist." He was torn between his divorced parents who attempted to "buy his attention, or flatly reject him." Lynn was a 16 year old girl characterized as "withdrawn and disinterested." She had been beaten and abused by her parents. Her sarcasm and steadfast refusal to cooperate in the most minor ways drove people from her within moments of meeting her. A social worker wrote that all three of the tutors were "angry, confused, hurt youngsters who had learned to mask their feelings under a facade of 'I don't care what the hell happens." It would be difficult to locate a group of young people with lower self-esteem.

All three of the tutors had been educationally tested at reading levels near the third grade, and none of them reported any positive educational experiences from previous school settings. However, since low self-concept seemed to be their most pressing concern, they were picked before other DH youth with similar learning problems.

Materials

The focus of the tutoring sessions was mainly reading comprehension on a first grade level and decoding. In addition, the tutors were given a variety of basic math materials, such as blocks, sticks, flash cards, etc., to help improve the tutees in this area as well. Self-concept was evaluated by a system initially designed by Luszki and Schmuck (1974). On this scale one notes the discrepancies, if any, between the individual's notion of actual-self to ideal-self. The author added several terms to this particular scale, for it was reasoned that they would indicate important aspects of self-esteem. Terms such as healthy, bored, close to teachers, close to parent(s), close with peers, successful, tired, etc., were added to this assessment device.

I Am:

I'd Like To Be:

\begin{tabular}{|l|c|c|c|c|c|c|}
\hline $\begin{array}{c}\text { Almost } \\
\text { Always }\end{array}$ & $\begin{array}{c}\text { Half of } \\
\text { the Time }\end{array}$ & $\begin{array}{c}\text { Hardly } \\
\text { Ever }\end{array}$ & $\begin{array}{c}\text { Almost } \\
\text { Always }\end{array}$ & $\begin{array}{c}\text { Half of } \\
\text { the Time }\end{array}$ & $\begin{array}{c}\text { Hardly } \\
\text { Ever }\end{array}$ \\
\hline & & & Friendly & & & \\
\hline & & & Bored & & & \\
\hline & & & Studious & & & \\
\hline & & & Likeable & & & \\
\hline & & & Happy & & & \\
\hline & & & Shy & & & \\
\hline & & & Smart & & & \\
\hline & & & Smart & & & \\
\hline & & & Mean & & & \\
\hline & & & Popular & & & \\
\hline
\end{tabular}




\begin{tabular}{|l|l|l|c|l|l|l|}
\hline & & & $*$ Close to: & & & \\
\hline & & & $*$ Classmates & & & \\
\hline & & & $*$ Dad & & & \\
\hline & & & $*$ Mom & & & \\
\hline & & & $*$ Sibling(s) & & & \\
\hline & & & Tired & & & \\
\hline & & & Honest & & & \\
\hline & & & Brave & & & \\
\hline & & & Lazy & & & \\
\hline & & & Cooperative & & & \\
\hline & & & Healthy & & & \\
\hline & & & Jealous & & & \\
\hline & & & Worried & & & \\
\hline
\end{tabular}

Teacher and tutor questionnaires were sent out at the end of the study to supply further insight and information regarding the program. These forms were very important to the project for they would reflect the effectiveness of the program from both tutor and teacher perspective. In addition, informal, in-depth, open interviews were conducted. It was reasoned that this qualitative research technique would provide additional relevant information and insight into the various facets of the program. Procedures

The tutors first attended two training sessions for the project. During these sessions, the tutors practiced and role-played how to reinforce correct statements from "their students" and how to properly correct mistakes. The tutors met with their students each school day for a $45-$ 60 minute period. Initially, in order to make sure that they would not abscond, a detention home staff had to escort them to and from the public school. The social worker also had to remain in the building while the tutoring was going on. Tutors had special sign-in sheets to mark their arrival and departure times. Weekly staff meetings were held between the program director (and author) and the tutors. At these informal meetings we discussed ideas, accomplishments of the previous week, and, of course, any personal gripes or issues that they had.

\section{Self-Concept}

\section{Results}

The self-concept scale was administered on a pre and post-test basis, to both the participants and the control group. All three tutors experienced dramatic gains in self-concept. The $\mathrm{N}$ for this trial project was too small to perform statistical analysis. Still the scores of the three DH tutors were so profound to serve as some indication of the program's success. The average decrease of discrepancies on this scale was 15 (Table 1) as compared with the control group who actually experienced an increase in the number of discrepancies on the post-test, from 23 to 25 .

It is reasoned that the lower the number of discrepancies the higher the self concept, for the "actual self" more nearly matches the individual's "ideal self." Only one of the DH control group showed a slight improvement on self-concept post scale, going from a score of 28 to 26 discrepancies. Based on the information generated from these scales, the tutors felt more confident of themselves both intellectually and emotionally. 
Table 1

Number of Discrepancies on Self-Concept Scale

\begin{tabular}{ccc}
\hline & Pre-Test & Post-Test \\
\hline Tutors & 1.26 & 1.8 \\
& 2.21 & 2.11 \\
& 3.24 & 3.5 \\
& $\mathrm{M}=23(15$ fewer discrepancies $)$ & \\
\hline Control & 1.28 & 1.26 \\
& 2.29 & 2.23 \\
& 3.22 & 3.26 \\
& $\mathrm{M}=23$ (Increase of two discrepancies) & $\mathrm{M}=25$ \\
\hline
\end{tabular}

\section{Teacher Questionnaires and Interview Feedback}

To nearly everyone's surprise, the tutors turned out to be true assets to the cooperating teachers and to their students. They described the tutors as "capable, sincere, and hard working young people" - a far cry from the labels the courts used to describe them. Teachers reported that the tutors assumed a variety of responsibilities, and that this load increased throughout the duration of the project. They noted that the tutors quickly adapted to their new roles and performed functions such as correcting exams and paper work, running off dittos, leading small math and reading groups, and escorting the class to and from various specials, like art and gym. All of the cooperating teachers indicated not only a willingness to carry on with the project, but, in fact, showed a strong desire to continue. One teacher wrote that she was "very disappointed that the project was ending - my tutor was such a big help to me!" Another stated that he had been "frustrated at the lack of help from city hall and all the 'red-tape' with large, special ed classes with no teacher assistants." The tutor had been like a "gift from above." Tutor Questionnaires and Interview Feedback

Based on tutor responses from both the questionnaires and the informal interviews, all three tutors found the project to be very successful. It was, in fact, quite remarkable to read their questionnaires for one would think that they had been filled out by college student teachers. For example, on the question "how can the program be improved?" the tutors wrote the following responses: "Suzy needs to work individually or with one other student so she won't be so distracted" and "Curtis must work with concrete objects before going into subtraction." John wrote that one of his tutees "needed more than praise, maybe some real rewards, like candy or stickers, or even movie tickets." When the teacher didn't follow through on his suggestion, he simply brought in some tangible rewards on his own. In other words, the tutors filled out these forms as teachers, not as troubled-individuals from a detention home. During the interview sessions, they indicated that this was their first real positive experience with "the system" in general, and with school in particular. Sean remarked that he was "tired of everyone trying to save us, when we proved we could save ourselves... all we needed was a real shot at it without somebody always breathing down our necks."

Report from Detention Home Staff

The following is a summary of the project from the director and social worker of the detention home.

At first they were nervous and slightly suspicious. Each had their fill of "programs that will help you." But this was different - they were helpers. Cautiously, they agreed to try. 
Within days the effects were noticeable. John, a loner who had no close friends in the home, emerged as a leader. A defensive non-reader, he began to pick up books - "So I can help my kids." A virtual school phobic, he looked forward to going to school. Intensely distrustful of adults and especially authority figures, he began to talk openly about "his" teacher, "his" supervisor Dr. Laz, and "our" school. His temper was still a problem and he still became easily frustrated, but when reminded that such behavior was inappropriate for someone working with kids, he began to seriously work on it. We knew he was onto to something mighty important when he decided to ride his bike (to tutor) in a downpour rather than stay back at the home, where he'd be nice and dry. He simply couldn't miss teaching his kids. Sean saw abundant opportunities to con everyone. Then he began to notice that he didn't have to. He was treated well, with respect, with the assumption that he was capable and responsible, and that he didn't have to play games to get it. Probably the most dramatic turnaround came with Lynn. A very angry, sarcastic, and bitter girl, she viciously bad-mouthed John and Sean for initially "ass-kissing" the staff. She resisted any attempt to deal with her attitude. But gradually, as she saw what was happening to the boys, she began very cautiously to ask questions about the program. Finally, we confronted her. It seemed she really wanted to get involved but couldn't back down from her stand. We agreed to let her see how it worked. Above the objections of John and Sean, who were sure she'd wreck "our program" by abusing her freedom, Lynn entered the program. Her current highly successful adjustment in a girl's residential program is attributed by her to the experiences she had as a student teacher in this unique project.

\section{Discussion}

Needless to say, due to such a small N, one must be careful to generate these positive results to other teens in the detention home system. Furthermore, it is possible that such high results were achieved due to the small director/tutor ratio, rather than the actual treatment itself. However, since the results were so promising, the program merits further testing with a larger $\mathrm{N}$ and control group. Since all of the cooperating teachers expressed a strong interest in continuing the project, it is very likely that tutoring projects such as these may offer inexpensive, workable solutions for teachers with large special needs class sizes with few or no assistants. At the present time, all of the tutors involved in this project have successfully left the detention home system to pursue community-oriented jobs. Upon conclusion of the project during the last staff meeting, the author asked the tutors to share some of their feelings about themselves and the project. Three salient points were expressed by the tutors: an increase in self-worth; an improvement in self-control; and a sense of responsibility to their students. "I don't want to happen to them what happened to me," John commented. They noted that this was the first time in their lives that they had been put in a position of giving, rather than always on the receiving end. Lynn remarked that she was "sick of people always looking at me like I'm some sort of reject, a loser." She added that the tutoring project gave her a chance to "prove "em wrong... that I'm good enough to help others." A salient factor which emerged from their interview responses was that they all felt more in control of their own lives and destiny than before. Further research might focus on locus-of-control, rather than a general notion of self-concept. These three tutors may have helped pave a route out of a system that often seems more like a dead-end than anything else, for dozens, perhaps hundreds like themselves. They have shown that they are willing, and indeed capable, to handle responsibility when given the proper circumstances and opportunity. 


\section{References}

Bullis, M., Yovanoff, P., Meuller, G., \& Havel, E. (2002). Life on the "outs" - Examination of the facility-to-community transition of incarcerated youth. Exceptional Children, 69, 722.

CaliberA.[Author: First initial missing.] (2002). The promise of law related education as delinquency prevention. Chicago, IL: American Bar Association Division for Public Education.

Empey, L.T., Stafford, M.C., \& Hay, C.H. (1999). American delinquency: Its meaning and construction $\left(4^{\text {th }}\right.$ ed.). Belmont, CA: Wadsworth.

Gautry, F. (1990). Cross-age tutoring in Frankley. Reading, 24, 21-27.

Henggeler, S.W. (1989). Delinquency in adolescence. Newbury Park, CA: Sage.

Kamps, D., Kravits, T., Stolze, J. \& Swaggart, B. (1999). Prevention strategies for at-risk students and students with EBD in urban elementary schools. Journal of Emotional \& Behavioral Disorders, 7, 112-118.

Lazerson, D. B. (1988). The effectiveness of cross-age tutoring with truant, junior high school students with learning disabilities. Journal of learning Disabilities, 21, 253-255.

Leone, P. E., Mayer, M. J., Malmgren, K., \& Misel, S. M. (2000). School violence and disruption: Rhetoric, reality and reasonable balance. Focus on Exceptional Children, 33, $1-20$.

Leschied, A. W., Jaffe, P. G., \& Willis, W. \& Willis, W. (1991). The young offenders act: A revolution in Canadian Juvenile Justice. Toronto, ON: University of Toronto Press.

Luszki, M. B., \& Schmuck, R. (1974). Diagnosing classroom learning environments. Chicago, IL: Science Research Associates.

Skiba, R. J., \& Peterson, R.L. (2000). School discipline at a crossroads: From zero tolerance to early response. Exceptional Children, 66, 335-347. 